\title{
Extracellular Histones Induced Eryptotic Death in Human Erythrocytes
}

\author{
Ka Wing Yeung ${ }^{a}$ Pui Man Lau ${ }^{a}$ Hing Lun Tsanga Ho Pui Ho ${ }^{b}$ Yiu Wa Kwanc \\ Siu Kai Kong ${ }^{\text {a }}$ \\ aProgramme of Biochemistry, School of Life Sciences, The Chinese University of Hong Kong, Shatin, \\ Hong Kong, China, 'Department of Biomedical Engineering, The Chinese University of Hong Kong, \\ Shatin, Hong Kong, China, 'School of Biomedical Sciences, The Chinese University of Hong Kong, \\ Shatin, Hong Kong, China
}

\section{Key Words}

Extracellular histones $・$ Erythrocytes $・$ Eryptosis $・$ Apoptosis $・$ Phosphatidylserine

\begin{abstract}
Background/Aims: Circulating or extracellular histones (EHs) in the bloodstream act as a damage-associated-molecular-pattern (DAMP) agent that plays a critical role in the pathogenesis of many diseases such as sepsis and sterile inflammation. To date, not much information is available to describe the mechanistic relationship between human erythrocytes and the cytotoxicity of EHs, the protein members from a highly conserved histone family across species. The present study explored this key question with a hypothesis that EHs induce eryptosis. Methods: Freshly isolated human red blood cells (RBCs) from healthy donors were treated with EHs or agents for positive controls in a physiological buffer for 3 or $24 \mathrm{~h}$. After treatments, flow cytometry was employed to quantify surface phosphatidylserine (PS) exposure from annexin-V-RFP binding, cell shrinkage from flow cytometric forward scatter (FSC) analysis, $\mathrm{Ca}^{2+}$ rise by fluo-4, reactive oxygen species (ROS) production by $\mathrm{H}_{2} \mathrm{DCFDA}$, and caspase- 3 activation by FAM-DEVD-FMK measurement. Hemolysis and membarne permeabilization were estimated respectively from hemoglobin release into supernatant and calcein leakage from RBC ghosts. Results: With positive controls for validation, EHs in the pathophsyiological range were found to accumulate annexin-V binding on cell surface, decrease FSC, upregulate ROS production, elevate $\mathrm{Ca}^{2+}$ influx and increase caspase-3 activity in a 3-h incubation. Of note, no RBC hemolysis and no calcein release from ghosts were obtained after EHs treatment for $24 \mathrm{~h}$. Interestingly, external $\mathrm{Ca}^{2+}$ was not a prerequisite for the EHs-mediated ROS production and PS externalization. Also, the eryptotic hallmarks in the apoptotic RBCs were partially blocked by heparin and antibody (Ab) against Toll-like receptor 2 (TLR2). Conclusion: EHs act as a DAMP agent in the human RBCs that induces eryptosis. The cytotoxic effect is rapid as the hallmarks of eryptosis such as cell shrinkage, surface PS exposure, $\left[\mathrm{Ca}^{2+}\right]$ i rise, ROS production
\end{abstract}




\section{Cellular Physiology Cell Physiol Biochem 2019;53:229-241 \\ \begin{tabular}{ll|l} 
and Biochemistry $10.33594 / 000000132$ & C 2019 The Author(s). Published by \\
Published online: 15 July 2019 & Cell Physiol Biochem Press GmbH\&Co. KG
\end{tabular} \\ Yeung et al.: Extracellular Histones Induced Eryptosis}

and caspase- 3 activation can be seen $3 \mathrm{~h}$ after treatment in a dose-dependent manner. The EHs' cytotoxic effects could be blocked by heparin and the Ab against TLR2.

\section{Introduction}

In human cells, DNA molecules are tightly packed and coiled around proteins called histones to form chromatins and nucleosomes in the cell nucleus. Histones are highly conserved basic proteins in mammals. In humans, there are five members in the histone family and they are the linker histones ( $\mathrm{H} 1$ and $\mathrm{H} 5)$ and core histones (H2A, H2B, H3 and H4) [1]. When cells are under stress and injury, histones in the cell nucleus are released extracellularly into the blood circulation. These circulating or extracellular histones (EHs) have been identified as a pathological trigger known as damage-associated molecular-pattern (DAMP) molecule in patients with trauma-induced lung injury [2], sepsis [3], autoimmune diseases [4], sterile inflammation [5] neuro-degeneration [6], thrombosis, acute respiratory distress syndrome and multiple organ failure $[7,8]$ among others.

According to the Danger-Injury model, most human diseases stem from disturbed cellular homeostasis as reflected by cell stress and injury [9]. Under these conditions, endogenous DAMP molecules such as EHs are released from cells after acute organ injury (AOI) [1]. EHs can then trigger secondary damages in other tissues eventually leading to danger of death in patients through non-infectious inflammation and organ failure $[1,9]$. In the pioneered work published in 2009 [10], Xu et al. demonstrated that mice died within 10 min after injecting calf thymus histones intravenously (75 mg per kg body weight) and the investigators concluded that EHs were potential molecular targets for therapeutics against sepsis and other inflammatory diseases [10]. In 2013, Abrams et al. reported that the blood histone level in patients with blunt traumatic lung injury was found in the range of 10 to $230 \mu \mathrm{g} / \mathrm{mL}$ while that in healthy subjects was $2.3 \mu \mathrm{g} / \mathrm{mL}$ [2]. Also, clinical data showed that the higher the level of EHs in patients, the more was the sever consequence and level of disease severity [11]. In 2017, Kordbacheh et al. established that EHs induced erythrocyte fragility and anemia [12]. However, towards to the mechanistic relationship between human red blood cells (RBCs) and EHs, not much information is available in the literature to date.

In the light of this, we hypothesized in this study that EHs work as a DAMP agent in human erythrocytes and set out to evaluate the pathological role of these EHs in human RBCs. In particular, we are interested in studying the cytotoxic effect of EHs and their mechanism on the induction of eryptosis, the programmed cell death in the human erythrocytes $[13,14]$. We reasoned that when EHs enter the blood circulation, erythrocytes will be the major cell type to be affected in the blood as RBCs contribute around one-quarter of the total cells in our body.

It is well known that human RBCs lack the mitochondria and nucleus and these organelles are major regulators of cell death programme [15]. Yet, human RBCs share a coordinated eryptosis programme for cell disposal akin to apoptosis in nucleated cells although some of the apoptotic hallmarks found in nucleated cells such as mitochondrial membrane depolarization, release of cytochrome $\mathrm{c}$ from the mitochondria, chromatin condensation and DNA fragmentation are absent $[13,14]$. During eryptosis, cells shrink and membrane blebs are formed on the cell surface. Also, the phosphatidylserine (PS) phospholipids are no longer restricted to the cytosolic part of the cell membrane but found on the outer-leaflet of the membrane as the 'eat-me' signals.

Mechanistically, apoptosis in human RBCs can be induced by energy depletion, oxidative stress with excess production of reactive oxygen species (ROS), increase in cytosolic free $\mathrm{Ca}^{2+}$ ion concentration ([Ca $\left.\left.{ }^{2+}\right] \mathrm{i}\right)$ and caspases activation [14]. The activation of caspase cascade eventually cleaves more than 500 cellular substrates including flappase and scramblase to expose surface PS [16]. With these 'eat-me' signals on cell membrane, apoptotic RBCs are swiftly engulfed by macrophages. This change in the PS location is an early hallmark of eryptosis and facilitates the cellular clearance by efferocytosis $[14,16]$ and adherence to 


\section{Cellular Physiology Cell Physiol Biochem 2019;53:229-241 \\ \begin{tabular}{c|c|c|c|} 
Dol: 10.33594/000000132 & O 2019 The Author(s). Published by \\
and Biochemistry Published online: 15 July 2019 & Cell Physiol Bichem Press Gmbsco
\end{tabular} \\ Yeung et al.: Extracellular Histones Induced Eryptosis}

the activated vascular endothelial cells with PS receptors under pathological conditons such as hypoxia [17]. Clinically, excessive eryptoses are observed in a wide variety of diseases such as G6PD deficiency and sickle-cell anemia. Conversely, inadequate eryptosis leads to the development of polycythemia vera, a blood disorder with too many RBCs [14].

\section{Materials and Methods}

\section{Materials and reagents}

EHs (Cat: H9250) purchased from Sigma-Aldrich were unfractionated whole histone isolated from calf thymus. Calcein/AM (Cat: C3100MP), fluo-4/AM (Cat: F14201) and $\mathrm{H}_{2}$ DCFDA (Cat: C6827) were obtained from Molecular Probes, Thermo Fisher Scientific. Alamar Blue (Cat: DAL1100) and FAM-DEVDFMK assay kits (Cat: FAM200-2) were respectively provided from Invitrogen, Thermo Fisher Scientific and Apologix, Cell Technology Inc. Anti-mouse IgG FITC conjugated secondary antibody (Ab) was from Abcam (Cat: ab97039). TLR2 (Cat: 16-9922-82), TLR4 (Cat: 16-9917-82) and mouse IgG2a kappa isotype control (Cat: 16-4724-85) antibodies were purchased from eBioscience, Thermo Fisher Scientific while heparin was from BD Biosciences. Ionomycin (Cat: CAY10004974) and hydrogen peroxide (Cat: 1072090250) were from Cambridge Bioscience and Merck Millipore, respectively. Annexin V-RFP was a recombinant protein produced by our laboratory.

\section{Isolation of human erythrocytes}

This study was approved by the Clinical Research Ethics Committee of The Chinese University of Hong Kong, the Hong Kong Special Administrative Region, China. Samples were obtained from healthy donors with informed consent using sterile lancets to pierce their fingertips and blood was collected in test tubes with anticoagulant. Human RBCs collected were then washed twice by centrifugation at $367 \mathrm{xg}$ with $\mathrm{Ca}^{2+} \mathrm{HEPES}$ buffer (in mM) (140 NaCl, $5 \mathrm{KCl}, 10$ HEPES, $2.5 \mathrm{CaCl}_{2}, 10$ Glucose, $0.1 \%$ (w/v) BSA, pH 7.4) and treated with reagents as indicated. To avoid sampling bias, comparisons of cellular responses were made within the same batch, and individual experiments were repeated with control (buffer solution only), solvent control (DMSO $(1 \%))$ and positive control (e.g. ionomycin $(1 \mu \mathrm{M})$ or $\left.\mathrm{H}_{2} \mathrm{O}_{2}(0.03 \%)\right)$.

\section{Hemolysis assay}

For the hemolysis assay, RBCs $\left(1.5 \times 10^{7} / \mathrm{mL}\right)$ were treated with different agents at $37^{\circ} \mathrm{C}$. After treatment, absorbance of supernatant was determined against blank at $415 \mathrm{~nm}$ with an ELISA plate reader (Bio-Rad) for the leakage of hemoglobin (Hb). Total cell lysis was obtained by adding Triton-X-100 (final concentration $0.1 \%(\mathrm{v} / \mathrm{v})$ ) into wells to release $\mathrm{Hb}$ into medium.

\section{Alamar Blue assay}

For the Alamar Blue assay, RBCs $\left(1.5 \times 10^{7} / \mathrm{mL}\right)$ were treated with different doses of EHs in the $\mathrm{Ca}^{2+}$ containing HEPES buffer containing $10 \%$ of Alamar Blue agent at $37^{\circ} \mathrm{C}$ for $24 \mathrm{~h}$. After treatment, fluorescence emission was monitored at $590 \mathrm{~nm}$ after excitation at $545 \mathrm{~nm}$ with a fluorescence plate reader (Tecan).

\section{Cell death assay}

Eryptosis in erythrocytes was determined as mentioned in our previous studies $[18,19]$. Briefly, RBCs were treated with different concentrations of EHs and doubly labelled with annexin-V-RFP and calcein/AM $(1 \mu \mathrm{M})$ for $30 \mathrm{~min}$ in dark at room temperature. Annexin-V-RFP labels the PS on cell surface. After crossing the plasma membrane, the non-fluorescent calcein/AM is converted into polar calcein by esterase in the cytosol, which is trapped intracellularly and emits fluorescence. However, in cells with leaky membrane, calcein diffuses out and the decrease in calcein signal reports membrane permeabilization.

For the measurement of $\left[\mathrm{Ca}^{2+}\right] \mathrm{i}, \mathrm{RBCs}$ were loaded with fluo-4/AM $(1 \mu \mathrm{M})$ at room temperature in dark for $30 \mathrm{~min}$. Similar to work with calcein/AM, polar fluo-4 is trapped inside the cytosol after cleavage the AM group from fluo-4/AM to fluo- 4 by esterase. The fluorescence of fluo-4 increases in a dose-dependent fashion when it bound to free $\mathrm{Ca}^{2+}$ ions. Changes in $\left[\mathrm{Ca}^{2+}\right] \mathrm{i}$ after treatment were measured with annexin-VRFP semi-quantitatively by flow cytometry. 


\section{Cellular Physiology Cell Physiol Biochem 2019;53:229-241

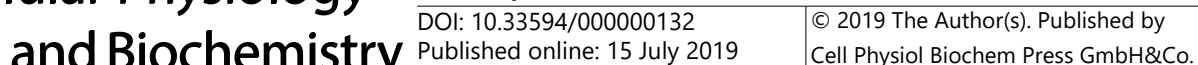 \\ Yeung et al.: Extracellular Histones Induced Eryptosis}

For the measurement of ROS production, 2',7'-dichlorodihydrofluorescein diacetate $\left(\mathrm{H}_{2} \mathrm{DCFDA}\right)$ was used to determine the change in cellular redox state towards oxidative stress. Briefly, human RBCs treated with EHs were stained with $\mathrm{H}_{2}$ DCFDA $(5 \mu \mathrm{M})$ and annexin-V-RFP at room temperature in dark for 20 min, followed by flow cytometric analysis using $\mathrm{H}_{2} \mathrm{O}_{2}(0.03 \%)$ as a positive control.

For the measurement of caspase- 3 activity, cells $\left(1 \times 10^{6} / \mathrm{mL}, 0.3 \mathrm{~mL}\right)$ were incubated with fluorogenic caspase-3 FAM-DEVD-FMK assay (Apologix) according to manufacturer's instruction (Cell Technology Inc.). After washing, cells were then mixed with annexin-V-RFP and incubated for $30 \mathrm{~min}$ in dark. Subsequently, cells were submitted to flow cytometric analysis after washing.

To explore the role of external $\mathrm{Ca}^{2+}$ in the eryptosis mediated by EHs, erythrocytes were treated with EHs in a $\mathrm{Ca}^{2+}$-free HEPES buffer (in mM) $(140 \mathrm{NaCl}, 5 \mathrm{KCl}, 10 \mathrm{HEPES}, 10$ Glucose, 2 EGTA, 0.1\% (w/v) BSA, $\mathrm{pH} 7.4$ ) at $37^{\circ} \mathrm{C}$ for $24 \mathrm{~h}$. Cells were then stained with annexin-V-RFP for $30 \mathrm{~min}$ in a $\mathrm{Ca}^{2+}$-containing HEPES buffer since the binding of annexin-V to PS is a $\mathrm{Ca}^{2+}$-dependent process. After washing, cells were subject to flow cytometric analysis. In these assays, $30 \mathrm{~min}$ incubation time is considered to be too short to trigger apoptosis [20-22] and controls were included for comparison.

Flow cytometric analysis was performed on a FACSVerse flow cytometer (BD Biosciences), using the FACSuite software for data acquisition and analysis. Green and red fluorescence were determined after excitation at $488 \mathrm{~nm}$ from a minimum of 10, 000 cells. In the two-variant flow cytometric dot plots, each dot represents one single cell, and the number at the corner of the dot plot shows the percentage of total cell population in the corresponding quadrant.

For the confocal microscopic analysis, cells after treatment were labeled with fluorochromes as mentioned above and observed under a confocal microscope after washing. Bright field and confocal images of cells were acquired with a confocal laser-scanning system (Leica SP8 Confocal System) fitted with an argon $(488 \mathrm{~nm}$ ) laser and a $552 \mathrm{~nm}$ laser for excitation. For fluorescence determination, annexin-V-RFP signal were measured using a 584-692 nm channel after excitation at $552 \mathrm{~nm}$. Likewise, the fluo- 4 signal were measured with a 500-574 $\mathrm{nm}$ channel after excitation at $488 \mathrm{~nm}$. Images were processed by Software LAS X (Leica).

\section{Ghost assay}

Ghosts from RBCs were prepared as described previously $[18,19]$. Briefly, freshly isolated erythrocytes were washed with Tris-buffered isotonic saline (0.15 M KCl, $10 \mathrm{mM}$ Tris, $\mathrm{pH} 7.4)$. The cells were then lysed and washed 3 times with 15 volumes of ice-cold hypotonic buffer ( $5 \mathrm{mM}$ Tris, $5 \mathrm{mM} \mathrm{KCl}, \mathrm{pH} 7.4$ ). After centrifugation, the pellet was loaded with calcein $(1 \mathrm{mg} / \mathrm{mL})$ in the ice-cold hypotonic buffer. To reseal the leaky ghosts, 0.1 volume of buffer $(1.5 \mathrm{M} \mathrm{KCl}, 50 \mathrm{mM}$ Tris, $\mathrm{pH} 7.4)$ was added to restore isotonicity, and the ghosts were incubated for $40 \mathrm{~min}$ at $37^{\circ} \mathrm{C}$. In this assay, digitonin, a nonionic detergent that selectively reacts with membrane cholesterol and permeabilizes plasma membrane, was used as a positive control. After treatments, ghost cells were analyzed by flow cytometry.

\section{Statistical analysis}

The differences between the control group and test group were analyzed for statistical significance by Student's t-test. All data points are mean \pm SEM from 3 sets of experiments completed on different dates, with RBCs from different donors.

\section{Statement of Ethics}

This study was approved by the Clinical Research Ethics Committee of The Chinese University of Hong Kong, the Hong Kong Special Administrative Region, China.

\section{Results}

EHs Induced Eryptosis in Human Erythrocytes without Hemolysis

Histones are highly conserved cationic proteins across species. Like other studies [2325], we employed calf thymus histones in this study to investigate their damaging effects in human RBCs. Freshly human RBCs were isolated from healthy individuals and incubated with histones ( 10 to $320 \mu \mathrm{g} / \mathrm{mL}$ ) for $24 \mathrm{~h}$ to evaluate the toxicity of EHs by a standard flow 
Fig. 1. EHs induce eryptosis in human RBCs. Freshly isolated human RBCs $\left(1.5 \times 10^{7} /\right.$ $\mathrm{mL}$ ) were treated with the agents as indicated at $37^{\circ} \mathrm{C}$ for $24 \mathrm{~h}$ in a $\mathrm{Ca}^{2+}$-HEPES buffer. After incubation, cells $\left(1 \times 10^{6} / \mathrm{mL}\right) \quad$ were stained with annexinV-RFP and calcein/ AM $(1 \mu \mathrm{M})$ for 30 min and subjected to flow cytometric or confocal microscopic analysis. (a) Number at the corner representing the \% of total population in the corresponding quadrant of the dot plots. (b) Percentage of the early eryptotic cells cells (annexin- $V^{\text {high }}$ / calcein $^{\text {high }}$ ) in the flow cytometric analysis after treatment with EHs for 24 (grey bar) or $3 \mathrm{~h}$ (white bar). (c) 3-h treatment data for FSC. (d) Confocal microscopic images from cells after 3-h treatment. Echinocytes (star-shape): arrow;

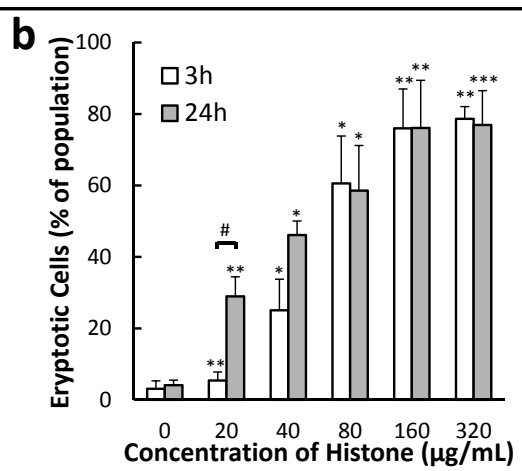

C
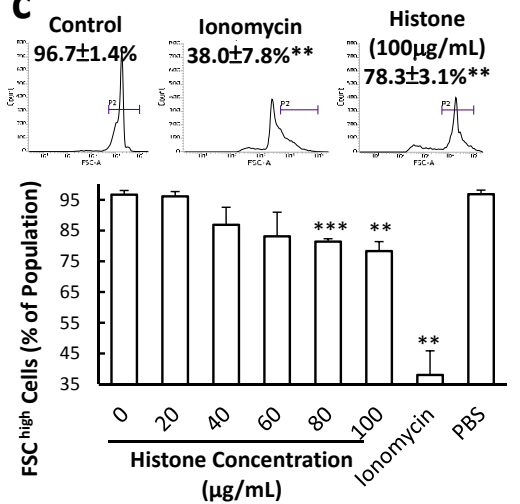

e

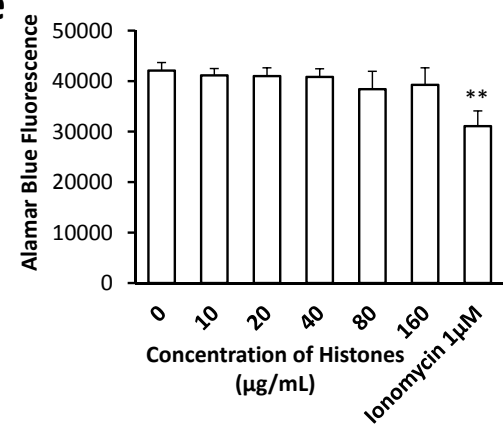

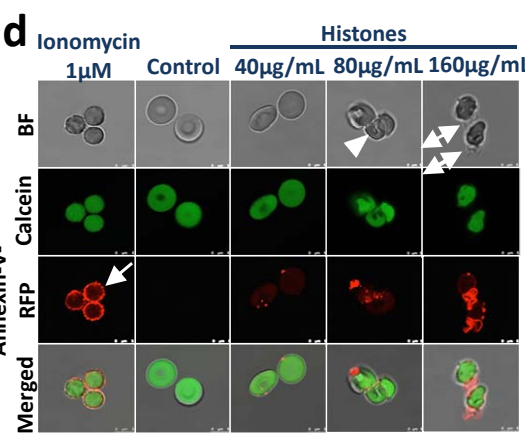

f

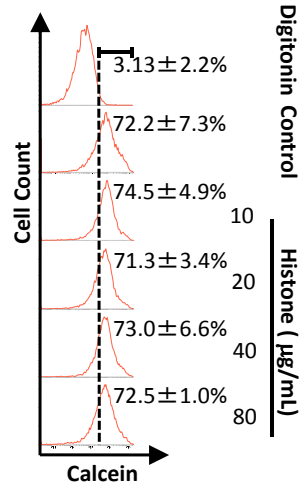

stomatocytes (cup-shape): arrow head and membrane blebs: double-arrow. Scale bar: $5 \mu \mathrm{m}$. (e) Metabolic activities from cells treated with the agents as indicated at $37^{\circ} \mathrm{C}$ for $24 \mathrm{~h}$ with Alamar Blue. (f) Ghosts entrapped with calcein (non-AM form) were treated with EHs or digitonin $(1 \mu \mathrm{M})$ at $37^{\circ} \mathrm{C}$ overnight. Calcein fluorescence was determined by flow cytometry for the degree of membrane permeabilization. Results are mean \pm SD $(n=3) .{ }^{*}<<0.05,{ }^{* *} p<0.01,{ }^{* * *} p<0.001$ relative to the control. $\# p<0.05$, relative to the response of the same concentration with 24-h treatment.

cytometric annexin-V-RFP and calcein/AM assay [26]. The concentration range of EHs used in the present study was based on the findings in healthy individuals $(2.3 \mu \mathrm{g} / \mathrm{mL})$ and patients with severe trauma in lungs $4 \mathrm{~h}$ after injury (10 to $230 \mu \mathrm{g} / \mathrm{mL}$ ) [2]. From Fig. 1a, it was found that around $90 \%$ of the human RBCs were annexin- $V^{\text {low }} /$ calcein $^{\text {high }}$ (cells located in the lower right quadrant in the control and solvent control), indicating that they were healthy with normal PS asymmetry and cell membrane integrity. In the positive control, ionomycin (1 $\mu \mathrm{M}$ ) significantly increased the number of cells in the upper right quadrant (72\%) and they were the early apoptotic cells (Annexin-V ${ }^{\text {high }} /$ Calcein $^{\text {high }}$ ). For the human RBCs treated with EHs (0 to $320 \mu \mathrm{g} / \mathrm{mL}$ ) for $24 \mathrm{~h}$, a dose-dependent increase in the early apoptotic cells was observed. It is noteworthy that not too many late eryptotic and/or necrotic cells $(<7 \%)$ were found in the upper left quadrant (Fig. 1a). Remarkably, early eryptosis was obtained when 
cells were treated with the EHs just for $3 \mathrm{~h}$ although a smaller percentage was obtained in the range of 20 to $40 \mu \mathrm{g} / \mathrm{mL}$ (Fig. 1b). At high concentrations ( $\geq 80 \mu \mathrm{g} / \mathrm{mL}$ ), no significant difference was found in the 3- and 24-h treated groups. With these findings in mind, we used lower concentrations of EHs $(<320 \mu \mathrm{g} / \mathrm{mL})$ in the later experiments. When RBCs undergo apoptosis, their size decreases. This could be determined by a decrease in the flow cytometric FSC signals. As can be seen in Fig. 1c, a dose-dependent reduction in FSC or cell size was observed when cells were treated with EHs for $3 \mathrm{~h}$.

Next, we examined whether EHs would have any effect on cell morphology during eryptosis other than cell shrinkage using confocal microscopy. As can be seen in Fig. 1d, untreated human RBCs showed the biconcave shape and they were discocytes. In the EHs-treated groups, cell aggregates with stomatocytes (cup-shape) and echinocytes (starshape) with a reduction in cell size were found. In Fig. 1d, we can see blebs on the surface of stomatocytes. As reported previously by other researchers [26], stomatocytes could be a result of a decrease in deformability after incorporating causative agent in the plasma membrane while echinocytic transformation was coupled to energy depletion. Interestingly, results from the Alamar Blue assay show that EHs did not alter much the metabolic activities of human RBCs in a $24 \mathrm{~h}$ treatment (Fig. 1e). This observation is compatible with the findings in Fig. 1d that most of the EHs-treated RBCs were stomatocytes. Of note, EHs did not elicit any hemolysis within the pathophysiological range (data not shown) nor calcein release from the RBC ghosts pre-loaded with calcein, given that the ghosts were permeabilized by digitonin for calcein release (Fig. 1f). In fact, similar results were obtained in Fig. 1a that we did not see many annexin- $V^{\text {high }} /$ calcein $^{\text {low }}$ cells for membrane permeabilization. Together, our observations suggest that direct cell membrane permeabilization and reduction in metabolic rate did not occur in the RBCs after EH treatment. However, the EHs eryptotic effect was concentration dependent and rapid.

\section{EHs Increased [ $\left.\mathrm{Ca}^{2+}\right]$ i and ROS Production in Human Erythrocytes}

Increase in the cytosolic $\left[\mathrm{Ca}^{2+}\right] \mathrm{i}$ and ROS are two important messengers for the induction of programmed cell death in human RBCs [28]. Therefore, it is logical to hypothesize that EHs are able to induce an increase in $\left[\mathrm{Ca}^{2+}\right] \mathrm{i}$, probably through the activation of the $\mathrm{Ca}^{2+}$ permeable non-selective cation channels, and increase in ROS as a result of impaired antioxidant defense. To test this hypothesis, we first determined the cell membrane PS scrambling and the change in $\left[\mathrm{Ca}^{2+}\right] \mathrm{i}$ simultaneously using annexin-V-RFP and fluo-4/AM, respectively. With EHs treatment for $3 \mathrm{~h}$, there was a dose-dependent increase in the doublepositive cell population (Annexin- $V^{\text {high }} /$ Fluo- $4^{\text {high }}$ ), demonstrating a rise in $\left[\mathrm{Ca}^{2+}\right] \mathrm{i}$ in the early eryptotic cells (Fig. 2a). With these observations, it seems likely that influx of $\mathrm{Ca}^{2+}$ ions from the external buffer might be a trigger of eryptosis. To explore this, we omitted $\mathrm{Ca}^{2+}$ by preparing a $\mathrm{Ca}^{2+}$-free HEPES buffer and depleted any residual $\mathrm{Ca}^{2+}$ ions with EGTA and challenged the RBCs again with EHs. As can be seen in Fig. 2b, depletion of external $\mathrm{Ca}^{2+}$ ions completely blocked the ionomycin's effect for the induction of eryptosis, indicating that $\mathrm{Ca}^{2+}$ rise was a trigger in the ionomycin-mediated eryptosis. Yet in the RBCs treated with EHs, only a small, but significant, reduction in percentage of the early eryptotic population was found (Fig. 2b). The extent was much smaller than that from the ionomycin-treated group. This indicates that influx of $\mathrm{Ca}^{2+}$ was not an absolute requirement in the $\mathrm{EH}$-induced eryptosis.

Likewise, a 3-h incubation of RBCs with EHs produced a dose-dependent increase in ROS in terms of the $\mathrm{H}_{2}$ DCFDA fluorescence in the annexin-V-positive cells in the $\mathrm{Ca}^{2+}$-HEPES buffer (Fig. 2c). Again, such ROS response from EHs-treated groups remained unchanged in the $\mathrm{Ca}^{2+}$-depleted buffer (Fig. 2d). In like manner, similar response was obtained from the $\mathrm{H}_{2} \mathrm{O}_{2}$ positive control in the $\mathrm{Ca}^{2+}$-containing and -free buffers (Fig. 2d). Again, ionomycin could not increase the ROS production in the $\mathrm{Ca}^{2+}$-free buffers but performed well in the $\mathrm{Ca}^{2+}$-containing buffer. Collectively, these findings provided evidence that $\mathrm{Ca}^{2+}$ was not a prerequisite for the ROS production as well as induction of eryptosis in the EHs-treated cells. 
Fig. 2. EHs increased $\left[\mathrm{Ca}^{2+}\right] \mathrm{i}$ and ROS in human RBCs. Freshly isolated human RBCs $\left(1.5 \times 10^{7} /\right.$ $\mathrm{mL}$ ) were treated with medium alone, ionomycin $(1 \mu \mathrm{M}), \mathrm{H}_{2} \mathrm{O}_{2}(0.03 \%)$ or EHs at the concentrations as indicated at $37^{\circ} \mathrm{C}$ for 3 $\mathrm{h}$ in the $\mathrm{Ca}^{2+}$-containing or -free HEPES buffer. After incubation, cells $\left(1 \times 10^{6}\right)$ $\mathrm{mL}$ ) were doubly stained with annexin-V-RFP and fluo-4/AM for $30 \mathrm{~min}$ (a), annexin-V-RFP and CM- $\mathrm{H}_{2}$ DCFDA $(5 \mu \mathrm{M})$ for 20 min (c, d) or annexinV-RFP and calcein/AM (1 $\mu \mathrm{M}$ ) for $20 \mathrm{~min}(\mathrm{~b})$ in the $\mathrm{Ca}^{2+}$-containing buffer for flow cytometric analysis. Results are mean \pm SD $(\mathrm{n}=3),{ }^{*} \mathrm{p}<0.05,{ }^{* *} \mathrm{p}<0.01$, $* * * \mathrm{p}<0.001 \quad$ relative to control; $\# \mathrm{p}<0.05$, $\# \# \mathrm{p}<0.01$, relative to the response of the same concentration in the $\mathrm{Ca}^{2+}$ free HEPES buffer.

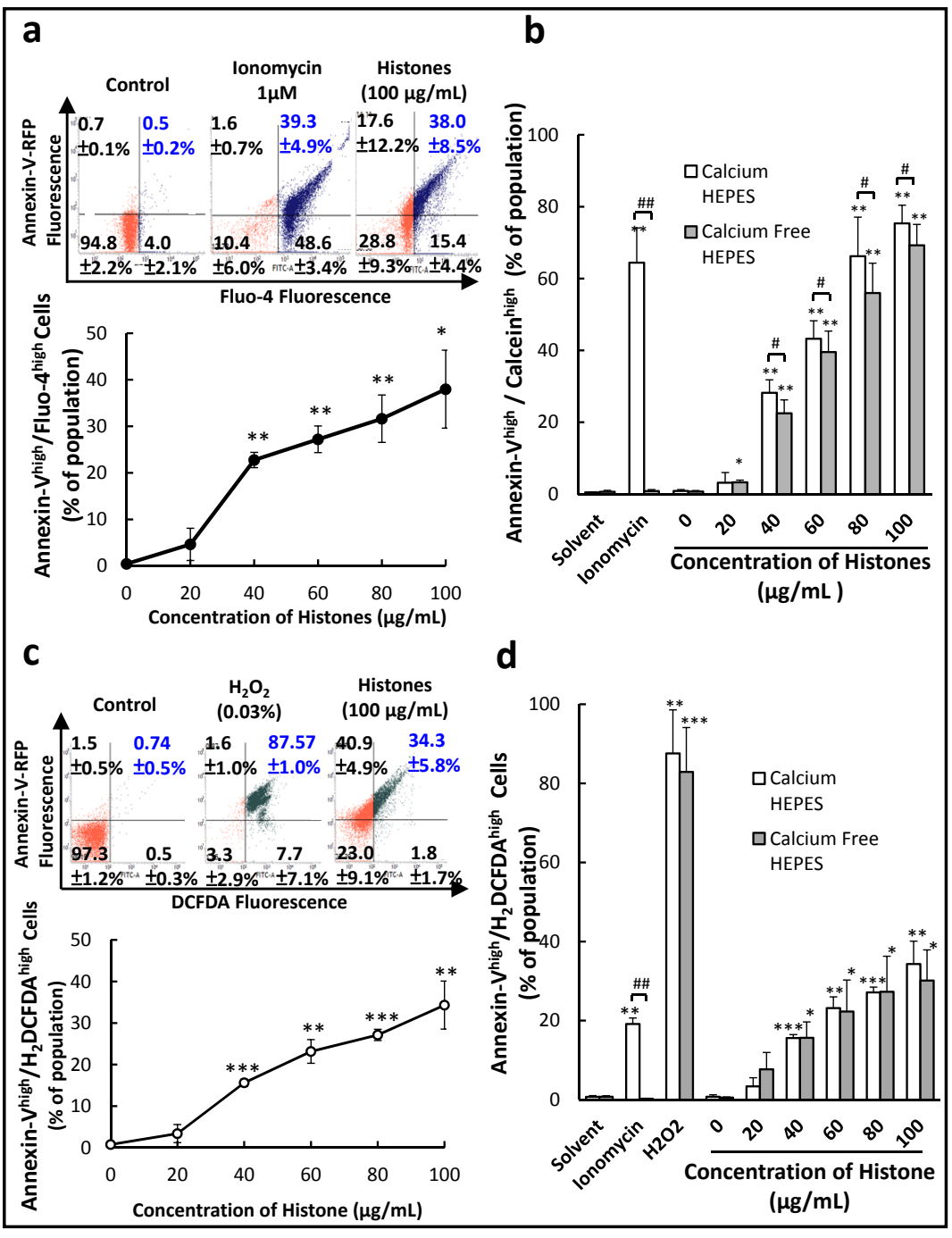

EHs Increased Caspase-3 Activity in Human Erythrocytes

Next, we tested the functional relevance of caspase- 3 activation in the EHs-mediated eryptosis. As shown in Fig. 3a, addition of EHs to RBCs for $3 \mathrm{~h}$ led to a dose-dependent activation of caspase-3 determined by FAM-DEVD-FMK. This conclusion is further supported by results that the response to EHs was attenuated by a caspase- 3 inhibitor (Ac-DEVD-CHO, $200 \mathrm{nM}$ ) in terms of caspase-3 activation and PS externalization (Fig. 3b). Interestingly, omission of the external $\mathrm{Ca}^{2+}$ increased caspase- 3 activation when cells were challenged with EHs at the concentration of $80 \mu \mathrm{g} / \mathrm{mL}$. No such enhancement was observed in the 40 $\mu \mathrm{g} / \mathrm{mL}$ treated group (Fig. 3c). Reason for these remains unclear at present. Taken together, our results show that both caspase- 3 activity and PS exposure in the EHs-treated RBCs were significantly reduced in the presence of caspase- 3 inhibitor. This suggests that caspase- 3 plays a significant role in the progression of EHs-mediated eryptosis.

Heparin and Antibdoy against TLR2 Protected Human RBCs from the EHs-triggered Eryptosis

It has recently become apparent that most DAMPs including EHs activate Toll-like receptor 2 and 4 (TLR2 and TLR4) on the cell surface [29]. To investigate this possibility, we used antibodies (Abs) against TLR2 and TLR4 to probe surface TLRs on the red cells with a corresponding secondary Ab conjugated with FITC. As shown in Fig. 4a, anti-TLR2 
Fig. 3. Role of caspase-3 in the EHs-mediated eryptosis. Freshly isolated human RBCs $\left(1.5 \times 10^{7} /\right.$ $\mathrm{mL}$ ) were treated with medium alone, ionomycin $(1 \mu \mathrm{M})$ or EHs at the concentration as indicated in the absence (a) or presence (b) of caspase-3 inhibitor (Ac-DEVD-CHO, $200 \mathrm{nM}$ ) at $37^{\circ} \mathrm{C}$ for $3 \mathrm{~h}$ in a $\mathrm{Ca}^{2+}$-containing $(\mathrm{a}, \mathrm{b})$ or $\mathrm{Ca}^{2+}$-free (c) buffer. After incubation, cells $\left(1 \times 10^{6}\right)$ $\mathrm{mL}$ ) were doubly stained with annexin-V-RFP and FAM-DEVD-FMK for 20 min and subjected to flow cytometric analysis. Results $\quad \%$ of subpopulation of annexin$V^{\text {high }} /$ FAM-DEVD-FMK ${ }^{\text {high }}$ $(\mathrm{a}, \mathrm{b})$ or MFI (c)) are mean \pm SD $\quad(n=3), \quad * \mathrm{p}<0.05$, ${ }^{* *} \mathrm{p}<0.01, \quad{ }^{* * *} \mathrm{p}<0.001$, relative to control. $\# \# p<0.01$, relative to the response of the same concentration of EHs.

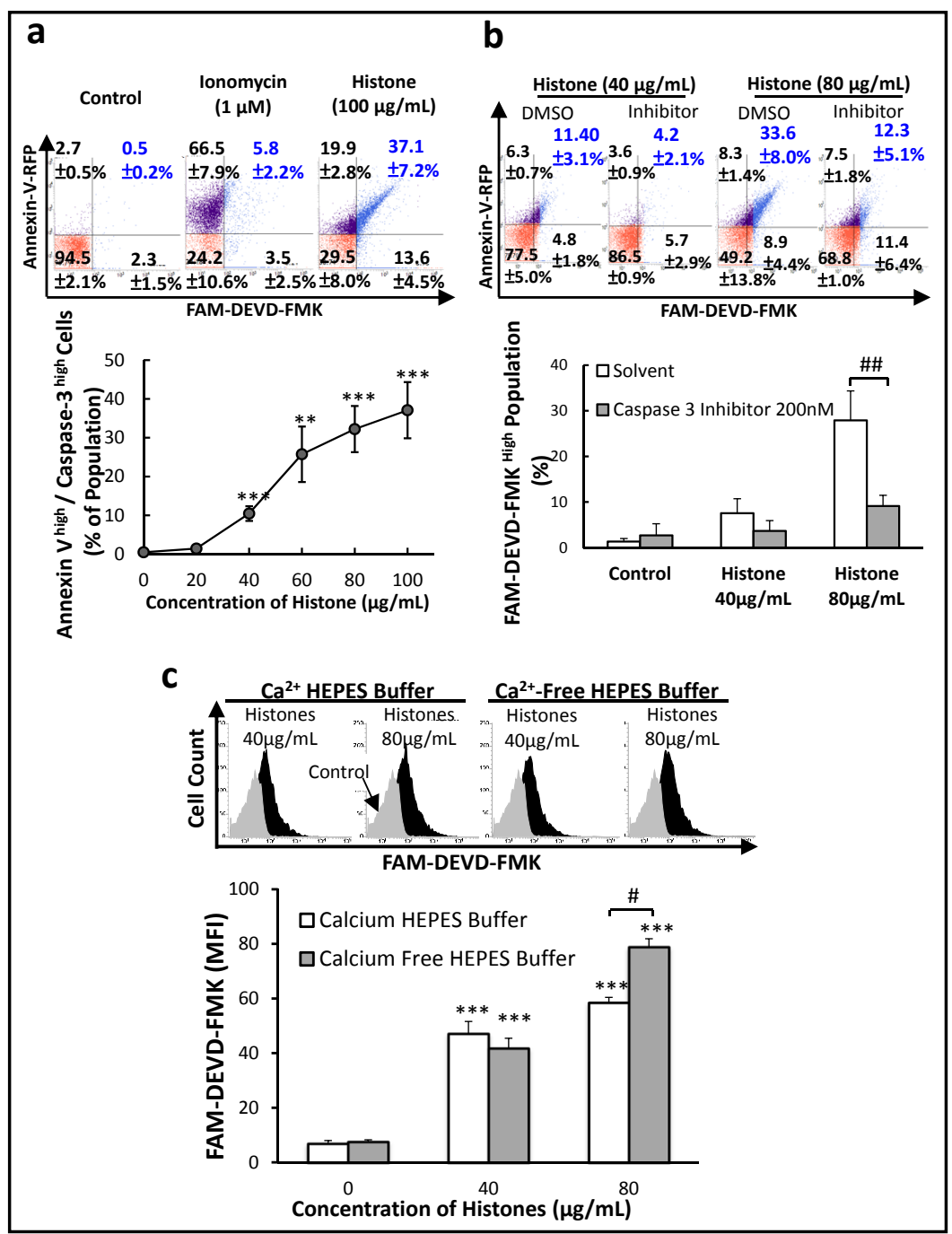

$\mathrm{Ab}$ signals were found by flow cytometry when compared to that of isotypic $\mathrm{Ab}$ under the same experimental conditions. Interestingly, no such observaton was obtained when the cells were incubated with the anti-TLR4 Ab (data not shown). We employed the neutralizing Abs again to block the effects of TLR2 and TLR4, if any, in the EHs-induced eryptosis. That neutralizing $\mathrm{Ab}$ against TLR2 was able to reduce both the PS externalization and caspase-3 activation (from $41 \%$ to $27 \%$ ) in the EHs-treated cells, while the TLR4 Ab or isotypic Ab did not (Fig. 4b), suggests that the EHs exert their eryptotic effects at least in part through the activation of surface TLR2.

Emerging evidence also suggests that heparin is able to ameliorate the damaging effects of EHs possibly due to the charge-charge interactions [30,31]. We therefore explored the effect of heparin on the EHs-elicited eryptosis. As shown in Fig. 4c, pretreatment of EHs with heparin for 15 min was able to inhibit their toxic effects. This inhibitory effect could also be observed after post-treatment. As can be seen in Fig. 4d, the earlier the addition of haparin $(1 \mathrm{U} / \mathrm{mL})$ to the cell culture with EHs, the stronger the protective effect. Together, these observations indicate that TLR Ab and heparin could be the protective agents against the EHs-mediated eryptotic effects. 
Fig. 4. The protective effect of heparin to eryptotic death. RBCs were incubated with the anti-TLR2 Ab or isotypic $\mathrm{Ab}$ for $1 \mathrm{~h}$ and probed with a secondary $\mathrm{Ab}$ conjugated with FITC to show the TLR2 on the red cell surface (a). RBCs were first preincubated with mouse monoclonal anti-human TLR2 or TLR4 blocking Abs $(50 \mu \mathrm{g} / \mathrm{mL})$ or control mouse IgG2a for $20 \mathrm{~min}$ at room temperature, and then treated with medium alone or EHs $(80 \mu \mathrm{g} /$ $\mathrm{mL}$ ) at $37^{\circ} \mathrm{C}$ for $24 \mathrm{~h}$ in a $\mathrm{Ca}^{2+}$ HEPES solution (b). After incubation, cells $\left(1 \times 10^{6} / \mathrm{mL}\right)$ were doubly stained with annexin-V-RFP and FAM-DEVD-FMK for 20 min and subjected to flow cytometric analysis. Heparin (1 U/mL) was added to EHs (40 or 80 $\mu \mathrm{g} / \mathrm{mL}$ ) for $15 \mathrm{~min}$ at room temperature for pre-treatment before culture (c). For post-

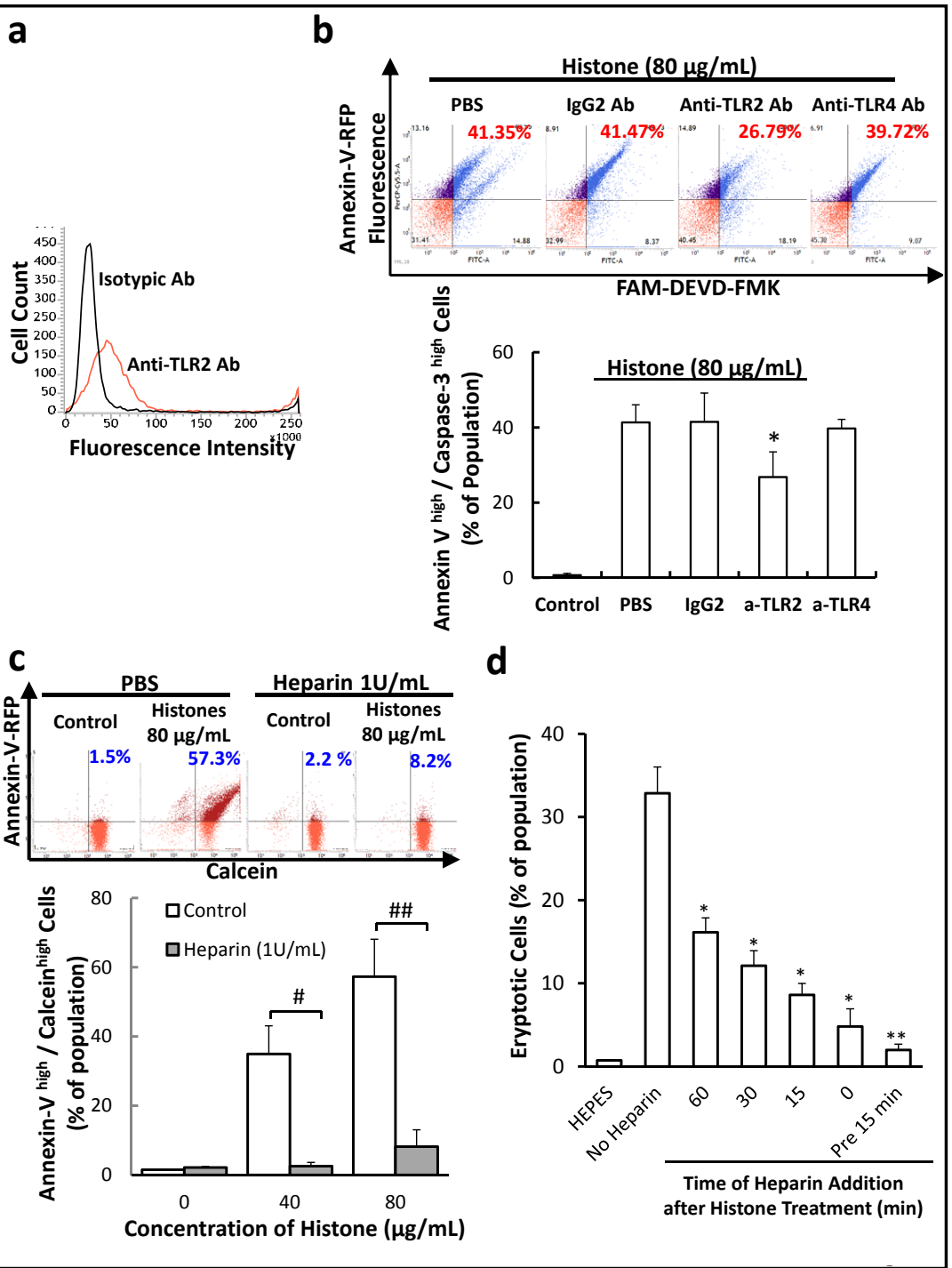
treatment, Heparin 1

$\mathrm{U} / \mathrm{mL}$ ) was added after EHs treatment at the time point as indicated (d). Subsequently, cells were incubated at $37^{\circ} \mathrm{C}$ for $3 \mathrm{~h}$ and doubly stained with annexin V-RFP and calcein/AM for $30 \mathrm{~min}$. Results are mean $\pm \mathrm{SD}$ $(\mathrm{n}=3),{ }^{*} \mathrm{p}<0.05,{ }^{* *} \mathrm{p}<0.01$ relative to control. $\# \mathrm{p}<0.05, \# \# \mathrm{p}<0.01$, relative to the response of the same EHs concentration.

\section{Discussion}

In this study, our data provide a mechanistic description on how EHs generate anemia [12], a common problem in the patients with sepsis [32], through the induction of eryptosis. Our results clearly demonstrate that EHs induces eryptosis in human erythrocytes in a dose dependent manner within the pathophysiological range of EHs found in the AOI patients. Also, the cytotoxic effect is rapid as the hallmarks of eryptosis such as cell shrinkage and surface PS exposure can be seen $3 \mathrm{~h}$ after the treatment. Evidently, $\mathrm{Ca}^{2+}$ influx, ROS production and caspase- 3 activation were found to be the cellular responses in the EHs-induced eryptosis. Yet, when the assays were performed in the absence of external $\mathrm{Ca}^{2+}$, activities associated with eryptosis including PS externalization, ROS generation and caspase-3 activation were not found altered in a very significant manner when compared to the results obatined in the 
Fig. 5. Schematic diagram showing how EHs elicit eryptosis in human erythrocytes. As the damage-associated-molecular-pattern (DAMP) molecules, extracellular histones (EHs) activate Toll-like receptor 2 (TLR2) or other receptors on the surface of human RBCs via a $\mathrm{Ca}^{2+}$-dependent and/or -independent pathway that elicit(s) the rise of reactive oxygen species (ROS) and activation of caspase-3 directly or indirectly. Eryptotic hallmarks such as cell shrinkage, externalization of phosphatidylserine and membrane blebbing are observed within a 3-hour incubation time. Yet, no membrane permeabilization in terms of hemolysis or calcein release from RBCs or RBC ghosts was observed 24 hours after EHs treatment. Heparin and anti-TLR2 Ab are able to block, at least in part, the EHs-mediated apoptosis in human erythrocytes.

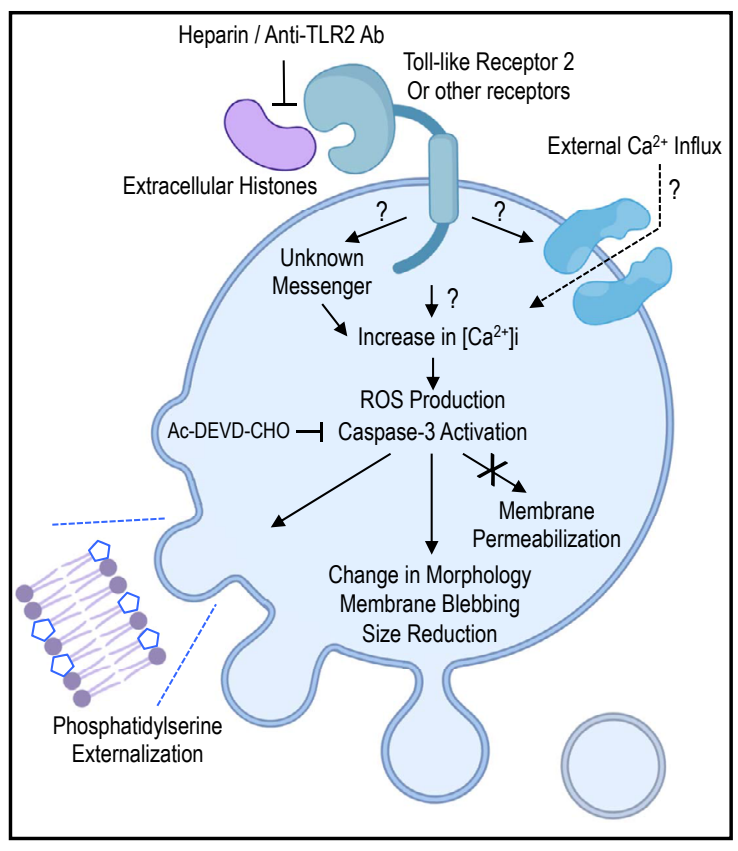

$\mathrm{Ca}^{2+}$-containing buffer. Another independent research group also demonstrated that both the natural and recombinant histones (H4) were able to induce eryptosis in healthy RBCs while heparin blocked the nature EHs-medaited PS externalization too [33]. In contrary to other studies that $\mathrm{Ca}^{2+}$ influx is important in the induction of eryptosis for various triggers $[14,21,33-39]$, our observations indicate that eryptosis is not mediated entirely through a $\mathrm{Ca}^{2+}$-dependent mechanism and similar phenomena have been reported in our laboratory and others before using different compounds. For example, human erythrocytes exposed to BAMLET (Bovine Alpha-lactalbumin Made LEthal to Tumor cells) undergo eryptosis in a $\mathrm{Ca}^{2+}$-independent fashion [40]. In our previous reports, similar observations were obtained in the eryptosis mediated by ferutinin [18] and polyphyllin D [19], which were not completely blunted by the depletion of external $\mathrm{Ca}^{2+}$.

In general, DAMP agents induce damages in the host cells by agonistic bindings to their cognate pattern recognition receptors (PRRs) including TLRs on cell surface. A number of studies have shown that EHs induce tissue injuries [10,41], thrombin generation in blood platelets [42] or procoagulant activities in endothelial cells [43] through the activation of TLR2 and TLR4. Also, it has been demonstrated that apoptosis induced by TLRs in acute myeloid leukemia cells [44] and neuronal and astroglial cells [45] is mediated by the activation of caspase-3. As both the TLRs and caspase-3 are found in human RBCs [46, 47], we examined this possibility and found that Ab against TLR2 but not TLR4 can partially suppress the EHs activity. Along this line, heparin as a negatively charged agent was found to neutralize the positively charged EHs and thus ameliorating their toxic effects in human RBCs in a pre- and post-treatment design. Collectively, our data identified a mechanism how the EHs interact with RBCs for the induction of eryptosis at least in part through the activation of surface TLR. We also provided results to show the protective effects from the TLR-2 neutralizing $\mathrm{Ab}$ and heparin (Fig. 5). Yet, many questions remain unanswered. For example, which member(s) in the histone family is/are the major contributor for the DMAP effects in human RBCs? How did the TLRs elicit their toxic effect? Is such toxic effect transmitted through the monomeric, homo- or hetero-dimeric form of TLRs since the TLR-2 neutralizing Ab only blocks the eryptoptic effect partially? How did the TLRs promote the ROS and $\left[\mathrm{Ca}^{2+}\right]$ i rise in human erythrocytes? As the EHs are positively-charged DAMPs, are there any other surface receptors apart from TLRs responsible for the eryptotic effects in human RBCs? These questions will definitely motivate further inquiry and additional experiments to deepen and expand our knowledge domain. Clinically, more work is also needed to determine whether 


\section{Cellular Physiology Cell Physiol Biochem 2019;53:229-241 \\ \begin{tabular}{ll|l} 
and Biochemistry & $\begin{array}{l}\text { DOl: 10.33594/000000132 } \\
\text { Published online: } 15 \text { July } 2019\end{array}$ & $\begin{array}{l}\text { O 2019 The Author(s). Published by } \\
\text { Cell Physiol Biochem Press GmbH\&Co. KG }\end{array}$ \\
\cline { 2 - 3 } &
\end{tabular} \\ Yeung et al.: Extracellular Histones Induced Eryptosis}

administration of heparin or antibodies against TLRs to block eryptosis could be a solution to treat anemia in the patients with AOIs.

\section{Abbreviations}

AOI (acute organ injury); [Ca $\left.{ }^{2+}\right]$ (cytosolic free $\mathrm{Ca}^{2+}$ ion concentration); DAMP (damage-associated-molecular-pattern); EHs (extracellular histones); $\mathrm{H}_{2}$ DCFDA (2',7'-dichlorodihydrofluorescein diacetate); $\mathrm{Hb}$ (hemoglobin); $\mathrm{IC}_{50}$ (the half maximal inhibitory concentration); MFI (mean fluorescence intensity); PRRs (pattern recognition receptors); PS (phosphatidylserine); RBCs (red blood cells); ROS (reactive oxygen species); TLR (Toll-like receptor).

\section{Acknowledgements}

This work is partially supported by a direct grant from the Faculty of Science, The Chinese University of Hong Kong (4053250). Fig. 5 in this article was created using BioRender.

SK Kong, YW Kwan and HP Ho conceived of and designed the research project. KW Yeung and HL Tsang performed assays. SK Kong, KW Yeung, PM Lau performed data analysis and wrote the manuscript. PM Lau provided logistics support.

\section{Disclosure Statement}

No conflicts of interest, financial or otherwise, are declared by the authors.

\section{References}

1 Silk E, Zhao H, Weng H, Ma D: The role of extracellular histone in organ injury. Cell Death Dis 2017;8:e2812.

2 Abrams ST, Zhang N, Manson J, Liu T, Dart C, Baluwa F, Wang SS, Brohi K, Kipar A, Yu W, Wang G, Toh $\mathrm{CH}$ : Circulating histones are mediators of trauma-associated lung injury. Am J Respir Crit Care Med 2013;187:160-169.

3 Ekaney ML, Otto GP, Sossdorf M, Sponholz C, Boehringer M, Loesche W, Rittirsch D, Wilharm A, Kurzai O, Bauer M, Claus RA: Impact of plasma histones in human sepsis and their contribution to cellular injury and inflammation. Crit Care 2014;18:543.

4 Gabler C, Kalden JR, Lorenz HM: The putative role of apoptosis-modified histones for the induction of autoimmunity in systemic lupus erythematosus. Biochem Pharmacol 2003;66:1441-1446.

5 Cui BB, Tan CY, Schorn C, Tang HH, Liu Y, Zhao Y: Neutrophil extracellular traps in sterile inflammation: the story after dying? Autoimmunity 2012;45:593-596.

6 Gilthorpe JD, Oozeer F, Nash J, Calvo M, Bennett DL, Lumsden A, Pini A: Extracellular histone H1 is neurotoxic and drives a pro-inflammatory response in microglia. F1000Res 2013;2:148.

7 Chen R, Kang R, Fan XG, Tang D: Release and activity of histone in diseases. Cell Death Dis 2014;5:e1370.

8 Xu Z, Huang Y, Mao P, Zhang J, Li Y: Sepsis and ARDS: The Dark Side of Histones. Mediators Inflamm 2015;2015:205054.

9 Buzas EI, György B, Nagy G, Falus A, Gay S: Emerging role of extracellular vesicles in inflammatory diseases. Nat Rev Rheumatol 2014;10:356-364.

10 Xu J, Zhang X, Pelayo R, Monestier M, Ammollo CT, Semeraro F, Taylor FB, Esmon NL, Lupu F, Esmon CT: Extracellular histones are major mediators of death in sepsis. Nat Med 2009;15:1318-1321.

11 Li X, Gou C, Yao L, Lei Z, Gu T, Ren F, Wen T: Patients with HBV-related acute-on-chronic liver failure have increased concentrations of extracellular histones aggravating cellular damage and systemic inflammation. J Viral Hepat 2017;24:59-67. 
12 Kordbacheh F, O>Meara CH, Coupland LA, Lelliott PM, Parish CR: Extracellular histones induce erythrocyte fragility and anemia. Blood 2017;130:2884-2888.

13 Daugas E, Candé C, Kroemer G: Erythrocytes: death of a mummy. Cell Death Differ 2001;8:1131-1133.

14 Lang F, Qadri SM: Mechanisms and significance of eryptosis, the suicidal death of erythrocytes. Blood Purif 2012;33:125-130.

15 Green DR, Kroemer G: The pathophysiology of mitochondrial cell death. Science 2004;305:626-629.

16 Kawano M, Nagata S: Efferocytosis and autoimmune disease. Int Immunol 2018;30:551-558.

17 Setty BN, Betal SG: Microvascular endothelial cells express a phosphatidylserine receptor: a functionally active receptor for phosphatidylserine-positive erythrocytes. Blood 2008;111:905-914.

18 Gao M, Wong SY, Lau PM, Kong SK: Ferutinin induces in vitro eryptosis/erythroptosis in human erythrocytes through membrane permeabilization and calcium influx. Chem Res Toxicol 2013;26:12181228.

19 Gao M, Cheung KL, Lau IP, Yu WS, Fung KP, Yu B, Loo JF, Kong SK: Polyphyllin D induces apoptosis in human erythrocytes through $\mathrm{Ca}^{2+}$ rise and membrane permeabilization. Arch Toxicol 2012;86:741-752.

20 Jilani K, Qadri SM, Lang E, Zelenak C, Rotte A, Bobbala D, Lang F: Stimulation of erythrocyte phospholipid scrambling by enniatin A. Mol Nutr Food Res 2011;55:S294-302.

21 Lang E, Jilani K, Zelenak C, Pasham V, Bobbala D, Qadri SM, Lang F: Stimulation of suicidal erythrocyte death by benzethonium. Cell Physiol Biochem 2011;28:347-354.

22 Mahmud H, Foller M, Lang F: Arsenic-induced suicidal erythrocyte death. Arch Toxicol 2009;83:107-113.

$23 \mathrm{Xu}$ J, Zhang X, Monestier M, Esmon NL, Esmon CT: Extracellular histones are mediators of death through TLR2 and TLR4 in mouse fatal liver injury. J Immunol 2011;187:2626-2631.

24 Kalbitz M, Grailer JJ, Fattahi F, Jajou L, Herron TJ, Campbell KF, Zetoune FS, Bosmann M, Sarma JV, HuberLang M, Gebhard F, Loaiza R, Valdivia HH, Jalife J, Russell MW, Ward PA: Role of extracellular histones in the cardiomyopathy of sepsis. FASEB J 2015;29:2185-2193.

25 Mena HA, Carestia A, Scotti L, Parborell F, Schattner M, Negrotto S: Extracellular histones reduce survival and angiogenic responses of late outgrowth progenitor and mature endothelial cells. J Thromb Haemost 2016;14:397-410.

26 Tanaka K, Fujimura-Kamada K, Yamamoto T: Functions of phospholipid flippases. J Biochem 2011;149:131143.

27 Reinhart WH, Chien S: Red cell rheology in stomatocyte-echinocyte transformation: roles of cell geometry and cell shape. Blood 1986;67:1110-1118.

28 Bissinger R, Bhuyan AAM, Qadri SM, Lang F: Oxidative stress, eryptosis and anemia: a pivotal mechanistic nexus in systemic diseases. FEBS J 2019;286:826-854.

29 Marsman G, Zeerleder S, Luken BM: Extracellular histones, cell-free DNA, or nucleosomes: differences in immunostimulation. Cell Death Dis 2016;7:e2518.

30 Kawai C, Kotani H, Miyao M, Ishida T, Jemail L, Abiru H, Tamaki K: Circulating extracellular histones are clinically relevant mediators of multiple organ injury. Am J Pathol 2016;186:829-843.

31 Li X, Ma X: The role of heparin in sepsis: much more than just an anticoagulant. Br J Haematol 2017;179:389-398.

32 Walsh TS, Saleh EE: Anaemia during critical illness. Br J Anaesth 2006;97:278-291.

33 Semeraro F, Ammollo CT, Esmon NL, Esmon CT: Histones induce phosphatidylserine exposure and a procoagulant phenotype in human red blood cells. J Thromb Haemost 2014;12:1697-1702.

34 Lang F, Lang KS, Lang PA, Huber SM, Wieder T: Mechanisms and significance of eryptosis. Antioxid Redox Signal 2006;8:1183-1192.

35 Lang F, Gulbins E, Lerche H, Huber SM, Kempe DS, Föller M: Eryptosis, a window to systemic disease. Cell Physiol Biochem 2008;22:373-380.

36 Lang F, Hoffmann EK: Role of ion transport in control of apoptotic cell death. Compr Physiol 2012;2:20372061.

37 Lang E, Qadri SM, Lang F: Killing me softly-suicidal erythrocyte death. Int J Biochem Cell Biol 2012;44:1236-1243.

38 Lang E, Lang F: Mechanisms and pathophysiological significance of eryptosis, the suicidal erythrocyte death. Semin Cell Dev Biol 2015;39:35-42.

39 Lang E, Bissinger R, Qadri SM, Lang F: Suicidal death of erythrocytes in cancer and its chemotherapy: A potential target in the treatment of tumor-associated anemia. Int J Cancer 2017;141:1522-1528. 


\section{Cellular Physiology and Biochemistry}

Cell Physiol Biochem 2019;53:229-241

\begin{tabular}{l|l}
\hline DOI: 10.33594/000000132 & (c) 2019 The Author(s). Published by
\end{tabular}

Yeung et al.: Extracellular Histones Induced Eryptosis

40 Hoque M, Nanduri R, Gupta J, Mahajan S, Gupta P, Saleemuddin M: Oleic acid complex of bovine $\alpha$-lactalbumin induces eryptosis in human and other erythrocytes by a $\mathrm{Ca}(2+)$-independent mechanism. Biochim Biophys Acta 2015;1850:1729-1739.

41 Allam R, Scherbaum CR, Darisipudi MN, Mulay SR, Hägele H, Lichtnekert J, Hagemann JH, Rupanagudi KV, Ryu M, Schwarzenberger C, Hohenstein B, Hugo C, Uhl B, Reichel CA, Krombach F, Monestier M, Liapis H, Moreth K, Schaefer L, Anders HJ: Histones from Dying Renal Cells Aggravate Kidney Injury via TLR2 and TLR4. J Am Soc Nephrol 2012; 23:1375-1388.

42 Semeraro F, Ammollo CT, Morrissey JH, Dale GL, Friese P, Esmon NL, Esmon CT: Extracellular histones promote thrombin generation through platelet-dependent mechanisms: involvement of platelet TLR2 and TLR4. Blood 2011;118:1952-1961.

43 Kim JE, Yoo HJ, Gu JY, Kim HK: Histones induce the procoagulant phenotype of endothelial cells through tissue factor up-regulation and thrombomodulin down-regulation. PloS One 2016;11:e0156763.

44 Eriksson M, Peña-Martínez P, Ramakrishnan R, Chapellier M, Högberg C, Glowacki G, Orsmark-Pietras C, Velasco-Hernández T, Lazarević VL, Juliusson G, Cammenga J, Mulloy JC, Richter J, Fioretos T, Ebert BL, Järås M: Agonistic targeting of TLR1/TLR2 induces p38 MAPK-dependent apoptosis and NFKB-dependent differentiation of AML cells. Blood Adv 2017;1:2046-2057.

45 Kim C, Spencer B, Rockenstein E, Yamakado H, Mante M, Adame A, Fields JA, Masliah D, Iba M, Lee HJ, Rissman RA, Lee SJ, Masliah E: Immunotherapy targeting toll-like receptor 2 alleviates neurodegeneration in models of synucleinopathy by modulating $\alpha$-synuclein transmission and neuroinflammation. Mol Neurodegener 2018;13:43.

46 Anderson HL, Brodsky IE, Mangalmurti NS: The evolving erythrocyte: Red blood cells as modulators of innate immunity. J Immunol 2018;201:1343-1351.

47 Hotz MJ, Qing D, Shashaty MGS, Zhang P, Faust H, Sondheimer N, Rivella S, Worthen GS, Mangalmurti NS: Red blood cells homeostatically bind mitochondrial DNA through TLR9 to maintain quiescence and to prevent lung injury. Am J Respir Crit Care Med 2018;197:470-480. 